\title{
Strategi Self Management Model Yates dan Model Cormier Terhadap Pengembangan Self Outonomy ditinjau dari Pola Asuh
}

\author{
Gede Danu Setiawan ${ }^{1}$, I Ketut Dharsana ${ }^{2}$ \\ ${ }^{12}$ Universitas Pendidikan Ganesha \\ e-mail: iketut.dharsana@undiksha.ac.id
}

Received March 01, 2018; Revised April 01, 2018; Accepted Mei 01, 2018; Published Online June, 302018

\section{Conflict of Interest Disclosures:}

The authors declare that they have no significant competing financial, professional or personal interests that might have influenced the performance or presentation of the work described in this manuscript.

\section{(c) (1) \\ This is an open access article distributed under the Creative Commons 4.0 Attribution License, which permits unrestricted use, distribution, and reproduction in any medium, provided the original work is properly cited. (2) 2018 by author}

\begin{abstract}
This study aimed to analyze: Self autonomy differences between students who take the Self techniques and techniques Yates Model Managament Managament Model Self Cormier, who in terms of parenting parents. The design of the posttest- desaign with $2 \times 2$ factorial design used in this study. The sample was 60 students of class X SMA Negeri 2 Singaraja. The results showed that: (1) There are differences between the Self autonomy of students who take the theory of behavioral counseling techniques Yates Self Managament Model with students who follow the theory of behavioral counseling techniques Self Managament Model Cormier. $(F=6642, p<0.05)$. (2) There is a difference Self autonomy students are nurtured with parenting acceptance to students who cared parenting rejection. $(\mathrm{F}=11714 ; \mathrm{p}<0.05)$. (3) There is an interaction effect between the theory of behavioral counseling and parenting parents against Self autonomy. ( $F=17.98 ; p<0.05)$. (4) There are differences between students Self autonomy raised by parenting acceptance to students who cared parenting rejection after following the techniques of behavioral theory Self Management Model Yates. ( $F=5,008$; $\alpha<2.048$ ). (5) There is a difference between student autonomy Self nurtured with parenting acceptance to students who cared parenting rejection after following the techniques of behavioral theory Self Management Model Yates. $(\mathrm{F}=7,008 ; \alpha<2.048)$. (6) There is a difference between student autonomy Self nurtured with parenting acceptance that follows the theory of behavioral techniques Yates Self Management Model with students who take the Self Management Model Cormier. ( $F=3,861 ; \alpha 2048)$. (7) There is a difference between student autonomy Self nurtured with parenting rejection that follows the theory of behavioral counseling techniques ModelYates with the Self Management Self Management Cormier follow techniques. ( $\mathrm{F}=2,252 ; \alpha$ $<2.048)$.
\end{abstract}

Keywords: Self Management Yates Technique, Self Management Cormier Technique, Parenting, Self Autonomy

How to Cite: Setiawan, G. D., \& Dharsana, I.K. 2018. Strategi Self Management Model Yates dan Model Cormier Terhadap

Pengembangan Self Outonomy ditinjau dari Pola Asuh. Bisma, 2 (1): pp. 48-57, DOI: 10.24036/XXXXXXXXXX-X 


\section{Pendahuluan}

Banyak siswa disekolah yang menunjukan sikap-sikap seperti kebutuhan yang bergantung kepada orang lain, datang dan pergi atas perintah dari orang lain, tidak mampu mengatakan atau menyampaikan pendapat yang sedang dipikirkan, dan dalam pengambilan sebuah keputusan selalu didominasi oleh orang lain. Disisi lain ada beberapa siswa yang menunjukan perilaku kebutuhan untuk bisa berdiri sendiri, bisa datang dan pergi sebagaimana diinginkan, mengatakan apa yang sedang dipikirkan, dan dalam mengambil keputusan tidak bergantung dengan orang lain. Berdasarkan perilaku yang ditunjukan oleh siswa tersebut diatas, maka siswa tersebut dapat dikatakan memiliki kepribadian Autonomy. Menurut Kamu Besar Bahasa Indonesai kata Autonomy atau Kemandirian adalah keadaan dapat berdiri sendiri;tidak bergantung kepada orang lain. Define tersebut mengandung indicator (1) berdiri sendiri, (2) tidak bergantung pada orang lain. Pengertian lain disebutkan oleh sorang ahli seperti Drust (1994:17) mengatakan bahwa "kemandirian merupakan kematangan pribadi, artinya manusia mandiri adalah pribadi bahagia yang sadar bahwa ia mempunyai arti bagi sesama." Definisi tersebut mengandung indicator (1) kematangan pribadi, (2) pribadi yang memiliki arti bagi sesame. Ahli lain seperti Dharsana (dalam sertifikat hasil pemeriksaan data psikologi,2009:2) menyebutkan pengertian dari Autonomy adalah kebutuhan untuk bisa berdiri sendiri meliputi bisa datang dan pergi sebagaimana diinginkan, mengatakan apa yang sedang dipikirkan oleh seseorang tidak bergantung pada orang lain dalam mengambil keputusan. Dari define tersebut mengandung indicator (1) bisa datang dan pergi sebagaimana diinginkan, (2) Mengatakan apa yang sedang dipikirkan , (3) tidak bergantung dengan orang lain dalam mengambil keputusan. Siswa merupakan agen perubahan dengan demikian perilakuperilaku yang muncul yang tidak mencerminkan dari tujuan pendidikan nasional. Dapat dijelaskan definisi pendidikan menurut UU Sistem Pendidikan Nasional Pasal 1 ayat 1 bahwa pendidikan adalah usaha sadar dan terencana untuk mewujudkan suasana belajar dan proses pembelajaran agar peserta didik secara aktif mengembangkan potensi dirinya untuk memiliki kekuatan spiritual keagamaan, pengendalian diri, kepribadian, kecerdasan, akhlak mulia, serta keterampilan yang diperlukan dirinya, masyarakat, bangsa dan negara. Untuk mengembangkan potesi peserta didik secara opimal, maka peserta didik harus bisa mengelola dirinya dengan baik. Sebagai guru pembimbing disekolah mengetahui terjadi gelaja seperti diatas maka sudah pastina dapat memikirkan beberpa jenis teori, teknik yang ada dalam bimbingan konseling. Untuk meningkatkan Self Outonomy siswa terdapat beberapa teknik yang dapat digunakan salah satunya adalah Behavioral. Teori Behavioral dipadukan dengan beberapa teknik didalam teori Behavioral agar memperoleh hasil yang maksimal. Teknik yang digunakan adalah teknik Self Managament Model Yates dan Self Management Model Cormier and Cormier. Edelson mengemukakan bahwa pada dasarnya self management adalah sebuah terminologi psikologis untuk menggambarkan proses pencapaian otonomi diri. Self management dalam terminologi pendidikan, psikologis, dan bisnis adalah metode, keterampilan dan strategi yang dapat dilakukan oleh individu dalam mengarahkan secara efektif pencapaian tujuan aktifitas yang mereka lakukan, termasuk didalamnya goal setting, planning, scheduling, taks tracking, dan selfevaluation. Menurut pendapat ahli lain seperti Yates 1985 menyebutkan bahwa "pengelolaan diri adalah suatu strategi yang mendorong individu untuk mampu mengarahkan prilaku - prilakunya sendiri dengan tanggung jawab atas tindakannya untuk mencapai kemajuan diri". Untuk mengembangkan pengelolaan diri secara efektif maka perlu dilakukan langkah - langkah dengan tahapan yang sistematis menggunakan prosedur yang jelas. 
Ada beberapa langkah-langkah pengembangan dan pelaksanaan pengelolaan diri yang efektif menurut Yates (1995) yaitu, dengan menggunakan prosedur sebagai berikut : (1) melakukan identifikasi terhadap tujuantujuan yang ada dalam diri siswa dengan mencatat melalui log-sheet (buku harian), (2) melakukan analisis diri untuk mengidentifikasi kekuatan dan kelemahan yang ada dalam diri siswa dilanjutkan dengan ditampilkan dalam bentuk grafik, (3) melakukan perubahan pengembangan diri dari data kekuatan dan kelemahan yang ada dalam diri siswa, (4) melakukan perbaikan diri pada aspek-aspek yang masih lemah dalam perubahan dan pengembangan perilaku yang disepakati dan diteguhkan dalam sesi pertemuan pengelolaan diri. Cormier \& Cormier (dalam Suarni :2004) juga menyatakan bahwa Self management atau pengelolaan diri adalah suatu strategi pengubahan perilaku yang dalam prosesnya konseli mengarahkan perubahan perilakunya sendiri dengan suatu teknik atau kombinasi teknik teurapetik. Berdasarkan beberapa pendapat diatas dapat disimpulkan bahwa pengelolaan diri atau self management adalah strategi menata prilaku individu yang bertujuan untuk mengarahkan dan mengelola dirinya agar dapat mencapai kemandirian dan hidupnya berjalan secara produktif. Dewasa ini banyak siswa khususnya pada jenjang SMA memiliki masalah-masalah yang berhubungan dengan self management. Dari hasil observasi disalah satu sekolah di Singaraja (SMA Negeri 2 Singaraja) terdapat beberapa siswa yang memiliki masalah yang berkaitan dengan rendahnya self management atau pengelolaan diri seperti kurang dapat mandiri dalam mengaktualisasi potensi diri yang dimiliki, setiap pilihannya masih didominasi oleh orang lain,kurangnya kreativitas, dan lainnya. Berkaitan dengan kemandirian Drust (dalam Suarni:2004) mengatakan bahwa "kemandirian merupakan kematangan pribadi, artinya manusia mandiri adalah pribadi bahagia yang sadar bahwa ia mempunyai arti bagi sesama." Definisi kemandirian juga dikatakan dalam menyatakan bahwa: Kemandirian itu diartikan sebagai kemampuan diri seseorang untuk menghasilkan "sesuatu" sebagai imbalan atau nilai tukar terhadap apa yang ditumbuhkan, yang dikonsumsi, dimiliki/dinikmati. Pada umumnya orang dengan mudah akan mengatakan bahwa mereka yang telah memiliki penghasilan sendiri untuk mencukupi keperluan hidupnya, itulah orang yang telah mandiri. Dari pendapat diatas dapat disimpulkan bahwa kemandirian adalah kemampuan yang dimiliki seseorang untuk dapat mengatur dirinya sendiri tanpa bergantung pada orang lain. Melihat kondisi siswa-siswa disekolah khususnya di SMA Negeri 2 Singaraja terlihat beberapa siswa memiliki permasalahan kemandirian khususnya dalam mengembangkan potensi yang dimiliki, masih banyak siswa dalam mengembangan potensi disekolah didominasi oleh temannya. Orang tua dan anak tidak dapat berbuat semena-mena, anak diberi kepercayaan dan dilatih untuk mempetanggung jawabkan segala tindakannya. Dengan melihat pendapat ahli diatas tidak meragukan bahwa pola asuh orang tua sangat mempengaruhi Outonomy siswa khususnya dalam pengembangan potensi diri, karena tiap pola asuh memiliki cara yang berbeda-beda untuk membebaskan tiap individu untuk dapat mengembangkan (eksplore) potensi baik minat maupun bakat yang dimiliki. Seperti contoh individu dengan pola asuh yang otoriter yang menekankan bahwa anak seperti "robot" karena harus menuruti perintah dari orang tuanya baik dalam melakukan apapun, sehingga akibat yang ditimbulkan adalah anak tersebut tidak dapat mandiri untuk mengembangkan potensi yang ada didalam dirinya seharunya dapat dikembangkan dengan optimal. Siswa dengan pola asuh demokratis akan beda perkembangan Outonomy yang dimiliki karena sifat pola asuh demokratis adalah memberikan anak sebebas-bebasnya dengan bertanggung jawab mengembangkan dirinya sesuai dengan bakat dan bakat yang dimiliki sehingga nisacaya siswa dnegan pola asuh demokratis dapat mandiri khususnya dalam mengembangkan potensi yang dimiliki. Adapun hipotesis dari penelitian ini adalah (1)Terdapat perbedaan self autonomy siswa yang mengikuti strategi Self Management Model Yates maupun model Cormier and Cormier. (2)Terdapat perbedaan self autonomy siswa yang memperoleh pola asuh otoriter dan pola asuh demokratis.(3)Terdapat pengaruh interaksi antara implementasi teknik konseling dengan pola asuh orang tua terhadap Self Outonomy. (4) Terdapat perbedaan self autonomy siswa dengan pola asuh otoriter dan self autonomy siswa dengan pola asuh demokratis setelah memperoleh perlakuan dengan strategi Self Management Model Yates, (5)Terdapat perbedaan self autonomy siswa dengan pola asuh otoriter dan self autonomy siswa dengan pola asuh demokratis setelah memperoleh perlakuan dengan strategi Self Management model Cormier and Cormier, (6) Terdapat perbedaan self autonomy anatara siswa dengan pola asuh otoriter yang memperoleh perlakuan dengan 
strategi Self Management Model Yates maupun model Cormier and Cormier, (7)Terdapat perbedaan self autonomy anatara siswa dengan pola asuh demokratis yang memperoleh perlakuan strategi Self Management Model Yates maupun model Cormier and Cormier.

\section{Metode}

Penelitian ini merupakan penelitian eksperimen. Rancangan yang digunakan adalah analisis two faktor design atau faktorial 2x2 (2 level variabel eksperimen dan 2 level variabel atribut). Populasi target dalam penelitian ini adalah seluruh siswa Kelas X SMA Negeri 2 Singaraja tahun pelajaran 2015/2016. Sedangkan pengambilan sampel dalam penelitian ini dilakukan dengan teknik purposive sampling. Peneliti akan mengambil sampel individu sebanyak 60 orang yang, yaitu 30 orang siswa dengan pola asuh acceptenace dan 30 siswa dengan pola asuh rejection. Kemudian membaginya menjadi 2 kelompok yaitu untuk kelompok yang diberikan teknik Self Management Model Yates dan Model Cormier and Cormier. Data pada penelitian ini dikumpulkan menggunakan kuesioner Self Autonomy yang terdiri dari 40 butir soal. Hasil analisis data pada uji coba instrument memberikan harga Alpha Cronbath sebesar 0.939. sesuai kriteria yang telah ditentukan, reliabilitas kuesioner Self Autonomy berada pada kategori sangat tinggi. Dengan demikian kuesioner Self Autonomy yang diuji cobakan memenuhi kriteria untuk digunakan dalam penelitian ini. Analisis data yang digunakan terdiri dari empat bagian, yaitu: (1) analisis deskripsi data, (2) uji prasayarat terdiri dari, uji normalitas sebaran data, uji homogenitas, (3) Uji hipotesis menggunakan Analisis Anava Dua Jalur (ANAVA AB), dan selanjutnya melakukan (4) Uji lanjut menggunakan t-scheffe.

\section{Hasil Dan Pembahasan}

Sebelum melakukan uji hipotesis terlebih dahulu dilakukan uji prasyarat analis. Hasil uji normalitas menunjukkan bahwa Chi-Kuadrat X2 menunjukkan bahwa seluruh kelompok memiliki harga X2 hitung lebih kecil daripada X2 tabel. Ini berarti H0 diterima (gagal ditolak), maka dua kelompok data berdistribusi normal. Hasil uji homogenitas menunjukkan bahwa menggunakan Levene's Test of Equality of Error Variance menunjukkan bahwa taraf signifikansi lebih besar dari 0.05 , maka varians setiap sampel sama (homogen), jika signifikansi diperoleh lebih kecil dari 0.05 , maka varians setiap sampel tidak sama (tidak homogen). Berdasarkan hasil analisis data telah terbukti bahwa terdapat efektifitas konseling behavioral Teknik Self Management Model Yates dan teknik Self Management Model Cormier terhadap Self Autonomy ditinjau dari pola asuh orang tua. Hal ini ditunjukkan dengan hasil sebagai berikut, (1) Terdapat Perbedaan Self Autonomy Antara Siswa Yang Mengikuti Teori Konseling Behavioral Teknik Self Management Model Yates Dengan Siswa Yang Mengikuti Teori Konseling Behavioral Teknik Self Managament Model Cormier ( $\mathrm{F}=6,624 ; \mathrm{p}<0.05)$, maka H0 yang menyatakan tidak terdapat perbedaan Self Autonomy antara kelompok siswa yang mengikuti konseling behavioral teknik Self Management Model Yates dengan siswa yang mengikuti konseling behavioral teknik Self Managament Model Cormier ditolak, sebaliknya H1 diterima. Jadi simpulannya bahwa terdapat perbedaan Self Outonomy antara siswa yang mengikuti teori konseling behavioral teknik Self Management Model Yates dengan siswa yang mengikuti teori konseling behavioral teknik Self Management Model Cormier. Rata-rata Self Outonomy kelompok siswa yang mengikuti teori konseling behavioral Self Management Model Cormier $\quad(=151,97)$ lebih rendah daripada siswa yang mengikuti teori konseling behavioral teknik Self Management Model Yates ( =168,37), (2) Terdapat Perbedaan Self Autonomy Antara Siswa Yang Diasuh Dengan Pola Asuh Acceptance Dan yang Diasuh dengan Pola Asuh Rejection ( $\mathrm{F}=11,71 ; \mathrm{p}<0.05)$, maka H0 yang menyatakan "tidak terdapat perbedaan Self Outonomy antara siswa yang memiliki pola asuh acceptance dengan siswa 
yang memiliki pola asuh rejection", ditolak, sebaliknya H1 diterima. Jadi simpulannya bahwa terdapat perbedaan Self Outonomy antara siswa yang memiliki pola asuh acceptance dengan siswa yang memiliki pola asuh rejection. Rata-rata self Outonomy kelompok siswa yang memiliki pola asuh aceptance ( = $161,23)$, dan rata-rata Self Outonomy kelompok siswa yang memiliki pola asuh rejection $(=144,57)$. Dari rata-rata tersebut, rata-rata Self Outonomy kelompok siswa yang memiliki pola asuh acceptance lebih tinggi dari kelompok siswa yang memiliki pola asuh rejection. (3) Terdapat pengaruh interaksi antara konseling behavioral dan pola asuh orang tua terhadap Self Autonomy $(F=17,98 ; p<0.05)$ maka H0 yang menyatakan tidak terdapat pengaruh interaksi antara teori konseling behavioral dan pola asuh orang tua terhadap Self Outonomy siswa", ditolak, sebaliknya H1 diterima. terdapat pengaruh interaksi antara teori konseling behavioral dan pola asuh orang tua terhadap Self Outonomy", diterima. Jadi, simpulannya adalah terdapat pengaruh interaksi antara teori konseling behavioral dan pola asuh orang tua terhadap Self Outonomy, (4) Terdapat Perbedaan Self Autonomy Antara Siswa Yang Diasuh dengan Pola Asuh Acceptance Dengan Siswa Yang Diasuh Dengan Pola Asuh Rejection Setelah Mengikuti Teori Konseling Behavioral Teknik Self Management Model Yates ( $\mathrm{t}=5.008 ; \alpha<2.048)$ maka H0 yang menyatakan "Tidak terdapat perbedaan self outonomy antara siswa yang diasuh dengan pola asuh acceptance dengan siswa yang diasuh dengan pola asuh rejection setelah mengikuti teori konseling behavioral teknik Self Management Model Yates", ditolak, sebaliknya H1 diterima. Jadi simpulannya bahwa Terdapat perbedaan Self autonomy antara siswa yang diasuh dengan pola asuh acceptance dengan siswa yang diasuh dengan pola asuh rejection setelah mengikuti teori konseling behavioral teknik Self Management Model Yates", diterima. Simpulan yang dapat ditarik menyatakan bahwa terdapat perbedaan Self autonomy antara siswa yang diasuh dengan pola asuh accceptance dengan siswa yang diasuh dengan pola asuh rejection setelah mengikuti teori konseling behavioral teknik Self Management Model Yates. Secara deskriptif rata-rata Self autonomy kelompok siswa yang diasuh dengan pola asuh acceptance yang mengikuti teori konseling behavioral teknik Self Management Model Yates $(=180.400)$ lebih tinggi dari pada kelompok siswa yang diasuh dengan pola asuh rejection yang mengikuti layanan konseling behavioral teknik Self Management Model Yates ( =161.862), (5) Terdapat Perbedaan Self Autonomy Antara Siswa Yang Diasuh dengan Pola Asuh Acceptance Dengan Siswa Yang Diasuh dengan Pola Asuh Rejection Setelah Mengikuti Teori Konseling Behavioral Teknik Self Management Model Cormier ( $\mathrm{t}=7.008 ; \alpha<2.048)$ maka H0 yang menyatakan "Tidak terdapat perbedaan Self autonomy antara siswa yang diasuh dengan pola asuh acceptance dengan siswa yang diasuh dengan pola asuh rejection setelah mengikuti teori konseling behavioral teknik Self Management Model Cormier", ditolak,sedangkan H1 diterima. Jadi simpulananya bahwa simpulan yang dapat ditarik menyatakan terdapat perbedaan Self autonomy antara siswa yang diasuh dengan pola asuh acceptance dengan siswa yang asuh dengan pola asuh rejection setelah mengikuti teori konseling behavioral teknik Self Management Model Cormier. Secara deskriptif rata-rata Self autonomy kelompok siswa yang diasuh dengan pola asuh acceptance yang mengikuti teori konseling behavioral teknik Self Management Model Cormier ( $=164.200$ ) lebih besar daripada kelompok siswa yang diasuh dengan pola asuh acceptance yang mengikuti teori konseling behavioral teknik Self Management Model Cormier ( =138.267), (6) Terdapat Perbedaan Self Autonomy Antara Siswa Yang Diasuh dengan Pola Asuh Acceptance Yang Mengikuti Teori Konseling Behavioral Teknik Self Management Model Cormier Dengan Yang Mengikuti Teori Konseling Behavioral Self Management Model Cormier $(\mathrm{t}=3.861 ; \alpha<2.048)$ maka H0 yang menyatakan Tidak terdapat perbedaan Need of deference antara siswa Perbedaan Self Autonomy Antara Siswa Yang Diasuh dengan Pola Asuh Acceptance Yang Mengikuti Teori Konseling Behavioral Teknik Self Management Model Cormier Dengan Yang Mengikuti Teori Konseling Behavioral Self Management Model Cormier ditolak, sebaliknya H1 diterima. Jadi simpulannya bahwa terdapat perbedaan terdapat perbedaan Self autonomy antara siswa diasuh dengan pola asuh acceeptance yang mengikuti teori konseling behavioral teknik Self Managament Model Yates dengan yang mengikuti teori konseling behavioral teknik Self Management Model Cormier. Secara deskriptif rata-rata Self autonomy kelompok siswa yang diasuh dengan pola asuh acceptance yang mengikuti teori konseling behavioral teknik Self Management Model Yates $(=180.400)$ lebih besar daripada kelompok siswa yang diasuh dengan pola asuh acceptance yang mengikuti teori konseling behavioral teknik

(Efektifitas Konseling Behavioral dengan Strategi Self Management Model Yates dan Model Cormier Terhadap Pengembangan Self Outonomy ditinjau dari Pola Asuh Orang Tua) 
Self Management Model Cormier (=164.200). (7) Terdapat Perbedaan Self Autonomy Antara Siswa Yang Diasuh dengan Pola Asuh Rejection Yang Mengikuti Teori Konseling Behavioral Teknik Self Managamant Model Yates Dengan Yang Mengikuti Teori Konseling Behavioral Teknik Self Management Model Cormier $(\mathrm{t}=2.252 ; \alpha<2.048)$ maka H0 yang menyatakan bahwa Tidak terdapat Perbedaan Self Autonomy Antara Siswa Yang Diasuh dengan Pola Asuh Rejection Yang Mengikuti Teori Konseling Behavioral Teknik Self Managamant Model Yates Dengan Yang Mengikuti Teori Konseling Behavioral Teknik Self Management Model Cormier ditolak, sebaliknya H1 diterima. Jadi simpulannya bahwa terdapat perbedaan Self autonomy antara siswa yang diasuh dengan pola asuh rejection yang mengikuti teori konseling behavioral teknik Self Management Model Yates dengan yang mengikuti teori konseling behavioral teknik Self Management Model Cormier. Secara deskriptif rata-rata Need of autonomy kelompok siswa yang diasuh dengan pola asuh rejection yang mengikuti teori konseling behavioral teknik Self Management Model Yates ( $=161.867$ ) lebih besar daripada kelompok siswa yang diasuh dengan pola asuh rejection yang mengikuti teori konseling behavioral teknik Self Managament Model Cormier ( = 138.267).

Konseling behavioral yang sering disebut sebagai konseling tingkah laku merupakan penerapan beragam teknik dan prosedur yang menerapkan prinsip belajar pada pengubahan tingkah laku kearah cara-cara yang lebih adaptif. Dalam penelitian ini, dua teknik yang digunakan untuk memberikan perlakuan terhadap Self autonomy, yaitu teknik Self Managament Model Yates dan teknik Self Managament Model Cormier. Asumsi yang mendasari penggunaan teknik Self Managament Model Yates menyebutkan bahwa "pengelolaan diri adalah suatu strategi yang mendorong individu untuk mampu mengarahkan perilaku perilakunya sendiri dengan tanggung jawab atas tindakannya untuk mencapai kemajuan diri" dalam teknik Self managamenet Model Yates terdapat 4 jenis metode yang dikembangkan dalam strategi pengelolaan diri atau self management yaitu : (a) pantau diri (self monitoring), (b) analisis diri (self analysis), (c) mengubah dii (self change), (d) pemeliharaan dan pertahanan diri (self maintance).Self Managament Model Cormier and Cormier merupakan teknik kedua. Asumsi dasar mengunakan teknik ini karna menurut Cormier \& Cormier (dalam Siti Nurzaakiyah, dkk : 13) juga menyatakan bahwa Self management atau pengelolaan diri adalah suatu strategi pengubahan perilaku yang dalam prosesnya konseli mengarahkan perubahan perilakunya sendiri dengan suatu teknik atau kombinasi teknik teurapetik. Cormier and Cormier menyebutkan beberapa strategi dari Self Management yang dapat diterapkan diantaranya (a) Patau diri (self monitoring), (b) Reinforcement yang positif (self-reward), (c) Penguasaan terhadap ransangan (stimulus control). Temuan empiris pada penelitian ini menyatakan bahwa terdapat perbedaan nilai Fhitung diperoleh sebesar 6,642 dan Ftabel sebesar 4,00. Jika dibandingkan nilai Fhitung dengan Ftabel didapatkan bahwa Fhitung $>$ Ftabel dengan taraf signifikansi $(\mathrm{p})<0,05$ maka dapat disimpulkan bahwa hipotesis nol yang menyatakan "tidak terdapat perbedaan Self Outonomy antara kelompok siswa yang mengikuti teori konseling behavioral teknik Self Management Model Yates dengan siswa yang mengikuti teori konseling behavioral teknik Self Management Model Cormier", ditolak. Sebaliknya hipotesis alternatif (H1) yang menyatakan bahwa "terdapat perbedaan Self Outonomy antara siswa yang mengikuti teori konseling behavioral teknik Self Management Model Yates dengan siswa yang mengikuti teori konseling behavioral teknik Self Management Model Cormier", diterima.

Jadi simpulannya bahwa terdapat perbedaan Self Outonomy antara siswa yang mengikuti teori konseling behavioral teknik Self Management Model Yates dengan siswa yang mengikuti teori konseling behavioral teknik Self Management Model Cormier. Rata-rata Self Outonomy kelompok siswa yang mengikuti teori konseling behavioral Self Management Model Cormier $(=151,97)$ lebih rendah daripada siswa yang mengikuti teori konseling behavioral teknik Self Management Model Yates ( $=168,37)$. Salah satu faktor yang memperngaruhi Need of autonomy seseorang adalah pola aasuh orang tua. Setiap orang tua memiliki pola asuh yang berbeda antara anak-anaknya. Pola asuh orang tua mempengaruhi perilaku dan sikap anak saat mereka berada di lingkungan pergaulan mereka. Pendidikan dalam keluarga mempengaruhi karakter masing-masing anak, maka dari itu betapa pentingnya pengasuhan, atau pola asuh dan pendidikan orang tua dalam pembentukan dan pertumbuhan anak. Chabib Thoha (1996:109) mengemukakan bahwa pola asuh 
orang tua adalah suatu cara yang ditempuh orang tua dalam mendidik anak sebagai perwujudan dari rasa tanggung jawab kepada anak. Peran keluarga menjadi penting untuk mendidik anak baik dalam sudut tinjau agama, tinjau sosial kemasyarakatan maupun tinjau individu. Jika pendidikan keluarga dapat berlangsung dengan baik maka mampu menumbuhkan perkembangan kepribadian anak menjadi manusia yang kuat dan mandiri, potensi jasmani dan rohani serta intektual yang berkembang secara optimal. Sikap dan perilaku anak yang diasuh dengan pola asuh acceptance tentu akan berbeda dengan sikap dan perilaku anak yang diasuh dengan pola asuh rejection. Hal ini tentu saja dipengaruhi oleh cara para orang tua mendidik anakanaknya. Anak yang diasuh dengan pola asuh acceptance akan lebih disayangi oleh kedua orang tuanya, diberikan kebebasan dan kepercayaan, orang tua selalu memantau perilaku anak, mengembangkan hubungan yang hangat dengan anak, sikap anak yang diasuh dengan pola asuh acceptance akan mampu bertanggung jawab, mau bekerjasama, tetapi anak yang disuh dengan pola asuh acceptance kadang kala terlalu dimanjakan sehingga akan bersifat egois. Sedangkan perilaku atau sikap anak yang diasuh dengan pola asuh rejection akan cenderung lebih pendiam, karena kurangnya perhatian dari orang tua, orang tua juga kurang memperdulikan kesejahteraan anak, dan menampilkan sikap permusuhan atau mendominasi anak, denngan pola asuh yang diterapkan orang tua kepada anak seperti itu maka perilaku anak akan mudah marah, tidak patuh, pemalu, dan sulitnya anak untuk bergaul. Setiap orang tua memiliki cara atau pola asuh tersendiri dalam mendidik anak-anaknya, namun setiap pola asuh yang diterapkan memiliki sisi positif maupun sisi negatifnya, itu semua tergantung bagaimana cara anak menyikapi atau menerima pola asuh yang diterapkan oleh orang tuanya.

Temuan empiris penelitian ini menyatakan bahwa terdapat perbedaan Need of autonomy antara siswa yang diaasuh dengan pola asuh acceptance dengan anak yang disuh dengan pola asuh rejection. nilai Fhitung diperoleh sebesar 11,714 dan Ftabel sebesar 4,00. Jika dibandingkan nilai Fhitung dengan Ftabel didapatkan bahwa Fhitung $>$ Ftabel dengan taraf signifikansi $(p)<0,05$ maka dapat disimpulkan bahwa hipotesis nol yang menyatakan "tidak terdapat perbedaan Self Outonomy antara siswa yang memiliki pola asuh acceptance dengan siswa yang memiliki pola asuh rejection", ditolak. Sebaliknya hipotesis alternatif (H1) yang menyatakan bahwa "terdapat perbedaan Self Outonomy antara siswa yang memiliki pola asuh acceptance dengan siswa yang memiliki pola asuh rejection", diterima. Jadi simpulannya bahwa terdapat perbedaan Self Outonomy antara siswa yang memiliki pola asuh acceptance dengan siswa yang memiliki pola asuh rejection. Rata-rata self Outonomy kelompok siswa yang memiliki pola asuh aceptance $(=161,23)$, dan rata-rata Self Outonomy kelompok siswa yang memiliki pola asuh rejection $(=144,57)$. Dari rata-rata tersebut, rata-rata Self Outonomy kelompok siswa yang memiliki pola asuh acceptance lebih tinggi dari kelompok siswa yang memiliki pola asuh rejection.

Rancangan analisis varians dua jalur dirancang untuk menampilkan interaction effect antara teori konseling behavioral dan pola asuh orang tua terhadap Need of Autonomy. Interaction effect merupakan pengaruh persilangan antara variabel baris dan variabel kolom yang digunakan. Selanjutnya hasil pengujian interaksi teori konseling behavioral dan pola asuh orang tua terhadap Need of autonomy diperoleh nilai Fhitung diperoleh sebesar 17,98 dan Ftabel sebesar 4,00. Jika dibandingkan nilai Fhitung dengan Ftabel didapatkan bahwa Fhitung $>$ Ftabel dengan taraf signifikansi $(\mathrm{p})<0,05$ maka dapat disimpulkan bahwa hipotesis nol yang menyatakan "tidak terdapat pengaruh interaksi antara teori konseling behavioral dan pola asuh orang tua terhadap Self Outonomy siswa”, ditolak. Sebaliknya, hipotesis alternatif (H1) yang menyatakan bahwa "terdapat pengaruh interaksi antara teori konseling behavioral dan pola asuh orang tua terhadap Self Outonomy", diterima. Jadi, simpulannya adalah terdapat pengaruh interaksi antara teori konseling behavioral dan pola asuh orang tua terhadap Self Outonomy

Karena terdapat pengaruh interaksi yang signifikan antara konseling behavioral dan pola asuh orang tua terhadap Self autonomy, maka dilanjutkan dengan pengujian signifikan masing-masing pola asuh orang tua, yaitu pada kelompok siswa yang diasuh dengan pola asuh acceptance dan siswa yang diasuh dengan pola asuh rejection dengan teori konseling behavioral teknik Self Mangemenet Model Yates. Hasil penelitian

(Efektifitas Konseling Behavioral dengan Strategi Self Management Model Yates dan Model Cormier Terhadap Pengembangan Self Outonomy ditinjau dari Pola Asuh Orang Tua) 
Berdasarkan hasil perhitungan diatas thitung diperoleh sebesar 5.008 dan $\mathrm{t}(28 ; 0.05)$ sebesar 2.048. Jika dibandingkan nilai thitung dengan $\mathrm{t}(\mathrm{dk} ; \alpha)$ didapatkan bahwa thitung $>\mathrm{t}(\mathrm{dk} ; \alpha)$ maka dapat disimpulkan bahwa hipotesis nol yang menyatakan "Tidak terdapat perbedaan self outonomy antara siswa yang diasuh dengan pola asuh acceptance dengan siswa yang diasuh dengan pola asuh rejection setelah mengikuti teori konseling behavioral teknik Self Management Model Yates", ditolak. Sebaliknya, hipotesis alternatif (H1) yang menyatakan bahwa "Terdapat perbedaan Self autonomy antara siswa yang diasuh dengan pola asuh acceptance dengan siswa yang diasuh dengan pola asuh rejection setelah mengikuti teori konseling behavioral teknik Self Management Model Yates", diterima. Simpulan yang dapat ditarik menyatakan bahwa terdapat perbedaan Self autonomy antara siswa yang diasuh dengan pola asuh acceeptance dengan siswa yang diasuh dengan pola asuh rejection setelah mengikuti teori konseling behavioral teknik Self Management Model Yates.

Secara deskriptif rata-rata Self autonomy kelompok siswa yang diasuh dengan pola asuh acceptance yang mengikuti teori konseling behavioral teknik Self Management Model Yates ( $=180.400)$ lebih tinggi dari pada kelompok siswa yang diasuh dengan pola asuh rejection yang mengikuti layanan konseling behavioral teknik Self Management Model Yates ( =161.862). Dengan membandingkan rata-rata Self autonomy kelompok siswa yang diasuh dengan pola asuh acceptance dan kelompok sisw ayang diasuh dengan pola asuh rejection ternayata rata-rata Need of autonomy kelompok siswa yang diasuh dengan pola asuh acceptance yang mengikuti teori konseling behavioral teknik Self management Model Yates lebih tinggi daripada kelompok siswa yang diasuh dengan pola asuh rejection yang mengikuti teori konseling behavioral teknik Self management Model Yates.

Berdasarkan hasil kajian teori konseling behavioral teknik Self Managamant Model Cormier terhadap pola asuh acceptance dan pola asuh rejection, diperoleh thitung diperoleh sebesar 7.008 dan $\mathrm{t}(28 ; 0.05)$ sebesar 2.048. Jika dibandingkan nilai thitung dengan $\mathrm{t}(\mathrm{dk} ; \alpha)$ didapatkan bahwa thitung $>\mathrm{t}(\mathrm{dk} ; \alpha)$ maka dapat disimpulkan bahwa hipotesis nol yang menyatakan "Tidak terdapat perbedaan Self autonomy antara siswa yang diasuh dengan pola asuh acceptance dengan siswa yang diasuh dengan pola asuh rejection setelah mengikuti teori konseling behavioral teknik Self Management Model Cormier", ditolak. Sebaliknya, hipotesis alternatif (H1) yang menyatakan bahwa "Terdapat perbedaan Self autonomy antara siswa yang diasuh dengan pola asuh acceptance dengan siswa yang diasuh dengan pola asuh rejection setelah mengikuti teori konseling behavioral teknik Self Management Model Cormier", diterima.

Ini berarti simpulan yang dapat ditarik menyatakan terdapat perbedaan Self autonomy antara siswa yang diasuh dengan pola asuh acceptance dengan siswa yang asuh dengan pola asuh rejection setelah mengikuti teori konseling behavioral teknik Self Management Model Cormier. Secara deskriptif rata-rata Self autonomy kelompok siswa yang diasuh dengan pola asuh acceptance yang mengikuti teori konseling behavioral teknik Self Management Model Cormier ( =164.200) lebih besar daripada kelompok siswa yang diasuh dengan pola asuh acceptance yang mengikuti teori konseling behavioral teknik Self Management Model Cormier ( =138.267). Berdasarkan kajian diatas, dapat dikatakan bahwa pelaksanaan teori konseling behavioral teknik Self Managament Model Cormier terhadap Self autonomy memiliki perbedaan pengaruh antara anak yang diasuh dengan acceptance maupun anak yang diasuh dengan pola asuh rejection. Hasil penelitian ini menunjukkan diperoleh sebesar 3.861 dan $\mathrm{t}(28 ; 0.05)$ sebesar 2.048. Jika dibandingkan nilai Fhitung diperoleh sebesar 3.861 dan $\mathrm{t}(28 ; 0.05)$ sebesar 2.048. Jika dibandingkan nilai thitung dengan $\mathrm{t}(\mathrm{dk} ; \alpha)$ didapatkan bahwa thitung $<\mathrm{t}(\mathrm{dk} ; \alpha)$ maka dapat disimpulkan bahwa hipotesis nol yang menyatakan "Tidak terdapat perbedaan Self autonomy antara siswa yang diasuh dengan pola asuh acceptance yang mengikuti teori konseling behavioral teknik Self Management Model Yates dengan yang mengikuti teori konseling behavioral teknik Self Management Model Cormier", ditolak. Sebaliknya, hipotesis alternatif (H1) yang menyatakan bahwa "Terdapat perbedaan Self autonomy antara siswa yang diasuh dengan pola asuh acceptance yang mengikuti teori konseling behavioral teknik Self Management Model Yates dengan yang mengikuti teori konseling behavioral teknik Self Management Model Cormier" diterima. 
Simpulan yang dapat ditarik menyatakan bahwa terdapat perbedaan Self autonomy antara siswa diasuh dengan pola asuh acceeptance yang mengikuti teori konseling behavioral teknik Self Managament Model Yates dengan yang mengikuti teori konseling behavioral teknik Self Management Model Cormier Secara deskriptif rata-rata Self autonomy kelompok siswa yang diasuh dengan pola asuh acceptance yang mengikuti teori konseling behavioral teknik Self Management Model Yates $(=180.400)$ lebih besar daripada kelompok siswa yang diasuh dengan pola asuh acceptance yang mengikuti teori konseling behavioral teknik Self Management Model Cormier ( =164.200).

Hasil penelitian ini menunjukkan perhitungan diatas thitung diperoleh sebesar 2.252 dan $\mathrm{t}(28 ; 0.05)$ sebesar 6.378. Jika dibandingkan nilai thitung dengan $\mathrm{t}(\mathrm{dk} ; \alpha)$ didapatkan bahwa thitung $>\mathrm{t}(\mathrm{dk} ; \alpha)$ maka dapat disimpulkan bahwa hipotesis nol yang menyatakan "Tidak terdapat perbedaan Self autonomy antara siswa yang diasuh dengan pola asuh rejection yang mengikuti teori konseling behavioral teknik Self Management Model Yates dengan yang mengikuti teori konseling behavioral teknik Self Managament Model Cormier", ditolak. Sebaliknya, hipotesis alternatif (H1) yang menyatakan bahwa "Terdapat perbedaan Self autonomy antara siswa yang diasuh dengan pola asuh rejection yang mengikuti teori konseling behavioral teknik Self Managament Model Yates dengan yang mengikuti teori konseling behavioral teknik Self Managament Model Cormier", diterima.

Simpulan yang dapat ditarik kesimpulan menyatakan bahwa terdapat perbedaan Self autonomy antara siswa yang diasuh dengan pola asuh rejection yang mengikuti teori konseling behavioral teknik Self Management Model Yates dengan yang mengikuti teori konseling behavioral teknik Self Management Model Cormier.

Secara deskriptif rata-rata Need of autonomy kelompok siswa yang diasuh dengan pola asuh rejection yang mengikuti teori konseling behavioral teknik Self Management Model Yates ( $=161.867)$ lebih besar daripada kelompok siswa yang diasuh dengan pola asuh rejection yang mengikuti teori konseling behavioral teknik Self Managament Model Cormier ( = 138.267).

Jadi dari hasil penelitian yang dilakukan di kelas X SMA Negeri 2 Singaraja bahwa terdapat perbedaan efektifitas konseling behavioral teknik Self Management Model Yates dan teknik Self Management Model Cormier terhadap Self Autonomy ditinjau dari pola asuh orang tua. Namun pengembangan lebih efektif menggunakan konseling behavioral teknik self Management Model Yates yang dilaksanakan pada siswa yang memiliki pola asuh acceptance. 


\section{Kesimpulan}

Berdasarkan hasil penelitian dan pembahasan, maka dapat diuraikan simpulan peneliti, yaitu sebagai berikut. (1) Terdapat perbedaan Self autonomy antara siswa yang mengikuti teori konseling behavioral teknik Self Managament Model Yates dengan siswa yang mengikuti teori konseling behavioral teknik Self Managament Model Cormier. ( $F=6.642 ; \mathrm{p}<0.05)$, (2) Terdapat perbedaan Self autonomy siswa yang diasuh dengan pola asuh acceptance dengan siswa yang diasuh dengan pola asuh rejection. $(F=11.714 ; \mathrm{p}<0.05)$, (3) Terdapat pengaruh interaksi antara teori konseling behavioral dan pola asuh orang tua terhadap Need of autonomy. ( $F=17.98 ; p<0.05)$, (4) Terdapat perbedaan Need of autonomy antara siswa yang diasuh dengan pola asuh acceptance dengan siswa yang diasuh dengan pola asuh rejection setelah mengikuti teori konseling behavioral teknik modeling. ( $F=5.008 ; \alpha<2.048)$, (5) Terdapat perbedaan Need of autonomy antara siswa yang diasuh dengan pola asuh acceptance dengan siswa yang diasuh dengan pola asuh rejection setelah mengikuti teori konseling behavioral teknik penguatan positif. ( $\mathrm{F}=7.008 ; \alpha<2.048)$, (6) Terdapat perbedaan Need of autonomy antara siswa yang diasuh dengan pola asuh acceptance yang mengikuti teori konseling behavioral teknik modeling dengan siswa yang mengikuti teori konseling behavioral teknik penguatan positif. ( $\mathrm{F}=3.861 ; \alpha 2.048)$, (7) Terdapat perbedaan Need of autonomy antara siswa yang diasuh dengan pola asuh rejection yang mengikuti teori konseling behavioral teknik modeling dengan yang mengikuti teori konseling behavioral teknik penguatan positif. ( $\mathrm{F}=2.252 ; \alpha<2.048)$.

\section{Referensi}

Corey., Gerald 2003. teori dan Praktek Konseling dan Psikoterapi. Bandung : PT. Refika Aditama.

Kartadinata, Sunaryo, et al. 2008. Penataan Pendidikan Profesi Konselor dan Layanan Bimbingan dan Konseling dalam Jalur Pendidikan Formal. Jakarta : Departemen Pendidikan Nasional

Suarni,Ketut.2004. Meningkatkan Motivasi Berprestasi Sekolah Menengah Umum di Bali dengan Strategi Pengelolaan Diri Model Yates (Studi Kuasi Eksperimental Pada Siswa Kelas 1 SMU di Bali).Disertasi (tidak diterbitkan).Yogyakarta. Universitas Gajah Mada.

Sukardi.2003. Metodelogi Penelitian Pendidikan. Jakarta : PT. Bumi Aksara

Undang-undang Sistem Pendidikan Nasional Pasal 1 Ayat 1 Tahun 2003

Yates, BT.1985. Self Management : The Science and The Art Of Helping Yourself. California: Ward Sworth Publishing.Co

Article Information (Supplementary)

Conflict of Interest Disclosures:

The authors declare that they have no significant competing financial, professional or personal interests that might have influenced the performance or presentation of the work described in this manuscript.

Copyrights Holder: < authors > <year>

Open Access Article | CC-BY Creative Commons Attribution 4.0 International License.

Word Count:
First Publication Right: BISMA The Journal of Counseling

Ccreative
commons 